\title{
PERILAKU BURUNG BAYAN SUMBA (Eclectus roratus cornelia Bonaparte) DI PENANGKARAN HAMBALA, SUMBA TIMUR, NUSA TENGGARA TIMUR (Behaviour of Bayan Sumba Bird (Eclectus roratus cornelia Bonaparte) in Hambala Captive Breeding, East Sumba, East Nusa Tenggara)*
}

\author{
Oleh/By: \\ Mariana Takandjandji ${ }^{1}$, Kayat ${ }^{2}$, dan/and Gerson ND. Njurumana ${ }^{2}$ \\ ${ }^{1}$ Pusat Litbang Hutan dan Konservasi Alam \\ Jl. Gunung Batu No. 5 Po Box 165; Telp. 0251-8633234, 7520067; Fax 0251-8638111 Bogor \\ ${ }^{2}$ Balai Penelitian Kehutanan Kupang \\ Jalan Untung Surapati No. 7 (belakang) Po. Box. 67 Kupang 85115 Telp. (0380) 823357, \\ Fax. (0380)831068 e-mail : aisuli@yahoo.com \\ *Diterima : 22 November 2006; Disetujui : 08 April 2010
}

\begin{abstract}
Behaviour of bayan sumba bird (Eclectus roratus cornelia Bonaparte) is necessarily observed to support the captive breeding in Hambala, East Sumba. This research aimed to identify the health, breeding ability, and process of adaptation of the bird to new environment to find out about proper management of captive breeding. Bird's behavior was directly observed in captivity. The research found that the bayan sumba bird in Hambala had four main behaviours consisting of 13 kinds activities. These behaviours were (1) moving consisted of flying, walking, fighting, and hanging activities, (2) idle consisted of perching, resting, and exposing himself to the sun activities, (3) ingestive covered eating, drinking, and cleaning up activities, and (4) mating consisted of approaching to attract a hen, touching head of hen (with his beak), and paying court to a hen activities. The averages of moving, idle, ingestive, and mating behaviour frequencies were 12.59, 16.5, 6.43, and 1.9 times respectively.
\end{abstract}

Keywords: Adaptation, behaviour, activity, frequency, ingestive

\begin{abstract}
ABSTRAK
Perilaku burung bayan sumba (Eclectus roratus cornelia Bonaparte) di penangkaran merupakan salah satu aspek penting yang perlu diamati agar dapat menunjang keberhasilan penangkaran di Hambala, Sumba Timur Pengamatan perilaku di penangkaran bertujuan untuk memperoleh informasi tentang kondisi kesehatan, kemampuan berbiak, dan proses adaptasi terhadap lingkungan sehingga dapat memberikan gambaran tentang pengelolaan burung. Metoda yang digunakan dalam penelitian ini adalah pengamatan langsung. Hasil penelitian menunjukkan bahwa burung bayan sumba di penangkaran Hambala, Sumba Timur, Nusa Tenggara Timur (NTT) memiliki 13 macam aktivitas harian yang digolongkan ke dalam empat perilaku utama yaitu perilaku bergerak, diam, ingestif, dan kawin. Perilaku bergerak ditunjukkan oleh aktivitas terbang, berjalan, berkelahi, dan menggelantung. Perilaku diam, dengan aktivitas bertengger, istrahat, dan berjemur. Perilaku ingestif dengan aktivitas makan, minum, dan membersihkan paruh, sedangkan perilaku kawin dengan akitivitas mendekati betina, menyelisik, dan mencumbu. Rata-rata frekuensi aktivitas dalam perilaku bergerak 12,59 kali, perilaku diam 16,5 kali, perilaku ingestif 6,43 kali dan perilaku kawin 1,9 kali.
\end{abstract}

Kata kunci: Adaptasi, perilaku, frekuensi, aktivitas, ingestif

\section{PENDAHULUAN}

Burung bayan sumba (Eclectus roratus cornelia Bonaparte) merupakan salah satu jenis burung paruh bengkok yang bernilai ekonomi tinggi. Jenis burung ini disukai orang untuk dipelihara karena memiliki warna bulu yang indah, jinak, dan dapat diajar untuk meniru suara manusia (Takandjandji et al., 2000). Perburuan dan penangkapan yang sering dilakukan untuk diperdagangkan secara tidak resmi dan terus-menerus menyebabkan populasinya di alam semakin berkurang, bahkan telah 
diambang kepunahan. Untuk mendukung upaya pelestarian burung bayan sumba, perlu dilakukan perlindungan terhadap habitat aslinya (in-situ) dan perlindungan di luar habitat (ex-situ) yakni dalam bentuk penangkaran.

Penangkaran terhadap burung bayan sumba merupakan salah satu bentuk pengelolaan populasi di luar habitat, dan diharapkan pemanfaatannya tidak lagi tergantung pada sumberdaya di alam yang jumlahnya sangat terbatas. Namun demikian penangkaran burung bayan sumba seringkali gagal karena kurangnya pengetahuan dan informasi mengenai perilaku burung tersebut.

Dalam rangka menunjang kegiatan penangkaran burung bayan sumba di Hambala, Kabupaten Sumba Timur, diperlukan pemahaman dan pengetahuan tentang perilaku. Pengetahuan tentang perilaku penting diketahui sebagai salah satu dasar utama dalam manajemen pengelolaan.

Pengenalan perilaku sudah berjalan sejak lama, terutama oleh masyarakat yang tergantung pada satwa buruan, yang mana perilaku dapat dimanfaatkan oleh pemburu untuk mengetahui keberadaan satwa buru dan untuk menjinakkan dan memelihara satwa. Prijono dan Handini (1996) mengatakan, perilaku dapat diartikan sebagai ekspresi satwa dalam bentuk gerakan-gerakan. Perilaku timbul karena adanya rangsangan yang berasal dari dalam tubuh individu atau dari lingkungannya dan perilaku satwa ini berfungsi untuk menyesuaikan diri terhadap perubahan lingkungan, baik dari luar maupun dari dalam (Tanudimadja, 1978). Beberapa pola perilaku terorganisasi dalam satu sistem perilaku spesies atau rangkaian pola pecahan yang mempunyai adaptasi umum yang sama. Selanjutnya dikatakan, satwa dilahirkan dengan berbagai pola perilaku yang sudah sempurna tetapi sebagian pola perilakunya berkembang di bawah pengaruh rangsangan lingkungan atau karena proses belajar.
Dengan mengetahui dan memahami perilaku satwa di penangkaran, maka kesehatan, perkembangbiakan, dan kemampuan satwa dalam beradaptasi dengan lingkungan akan dapat dipantau. Pengelolaan akan lebih baik apabila ditunjang oleh pengamatan yang mengarah pada proses adaptasi terhadap lingkungan di luar habitat untuk proses domestikasi. Khusus pada burung, pengenalan perilaku perlu diketahui untuk mendapatkan metode pemeliharaan yang tepat, terutama perilaku makan karena sangat berguna untuk menentukan palatabilitas suatu pakan. Kemampuan adaptasi untuk merubah perilaku dalam lingkungan yang baru merupakan salah satu penentu dalam mempersiapkan satwa di penangkaran.

Penelitian ini bertujuan untuk memperoleh informasi tentang perilaku terutama proses adaptasi burung bayan sumba hasil penangkaran Oilsonbai yang dipindahkan ke lokasi penangkaran di Kawasan Hutan Dengan Tujuan Khusus (KHDTK) Hambala. Diharapkan tulisan ini bermanfaat sebagai model dalam memasyarakatkan teknik penangkaran guna pengembangan populasi burung bayan sumba sebagai aspek konservasi $e x$-situ.

\section{METODE PENELITIAN}

\section{A. Lokasi dan Waktu Penelitian}

Penelitian dilakukan di penangkaran burung bayan sumba di KHDTK Hambala, Kabupaten Sumba Timur, Provinsi Nusa Tenggara Timur (NTT), secara intensif untuk mengamati perilaku terutama proses adaptasi, dalam waktu 24 hari mulai jam 06.00 sampai dengan 18.00 pada bulan Desember 2003.

\section{B. Bahan dan Alat Penelitian}

Bahan yang digunakan adalah dua pasang burung bayan sumba hasil penangkaran di Oilsonbai, Kabupaten Kupang, pakan (biji-bijian, buah-buahan, dan sayuran), obat-obatan, sangkar kawat, sa- 
rung tangan, jaring, ember, selang, piring, mug kaleng untuk makan dan minum, hand spray, sikat kawat, dan sapu lidi. Alat yang digunakan adalah kamera, meteran, senter, dan alat tulis. Burung bayan hasil penangkaran Oilsonbai dibawa menuju lokasi baru di Hambala menggunakan transportasi laut selama sehari semalam. Selama dalam perjalanan, burung bayan ditempatkan dalam sangkar kawat berbentuk lingkaran berdiameter $40 \mathrm{~cm}$ sebanyak dua buah sehingga masing-masing sangkar berisi satu pasang. Setelah tiba di Hambala, burung bayan langsung dimasukkan ke dalam kandang perkembangbiakan.

\section{Cara dan Cakupan Pengamatan Perilaku}

Proses adaptasi burung bayan di penangkaran diketahui melalui pengamatan aktivitas dan perilaku. Perilaku burung yang diamati adalah bergerak, diam, ingestif, dan sosial. Perilaku bergerak meliputi aktivitas terbang, berjalan, menggelantung, dan berkelahi; perilaku diam meliputi aktivitas bertengger, berjemur, dan istirahat; perilaku ingestif termasuk aktivitas makan, minum, dan membersihkan paruh; sedangkan perilaku kawin meliputi aktivitas mendekati betina, menyelisik, dan bercumbu. Pengamatan aktivitas dilakukan pada setiap ekor burung selama enam hari.

Pengamatan dilakukan pada setiap ekor burung dalam kandang perkembangbiakan, yakni dengan mengetahui kondisi burung melalui perilaku tampilannya. Pencatatan aktivitas dilakukan sepanjang hari untuk mengetahui rata-rata waktu setiap aktivitas dan frekuensi kegiatan per hari.

Batasan aktivitas burung bayan dalam penelitian ini adalah:

1. Perilaku bergerak, dengan aktivitas :

a. Terbang, yaitu aktivitas yang dilakukan dengan menggunakan sayap sambil mengeluarkan suara. b. Berjalan, adalah aktivitas yang dilakukan dengan cara berpindah tempat menggunakan kaki di lantai kandang.

c. Berkelahi, adalah aktivitas yang dilakukan secara sosial namun agresif dengan cara menggigit burung bayan lainnya.

d. Menggelantung, adalah aktivitas yang dilakukan dengan cara naik atau memanjat kawat, menggigit kawat atau kayu untuk bergerak dan berpindah tempat. Aktivitas ini dilakukan dengan menggunakan kaki dan paruh untuk menggaet kawat, kadang-kadang bagian kepala posisinya di bawah.

2. Perilaku diam, dengan aktivitas:

a. Bertengger, adalah aktivitas pasif yang dilakukan dengan posisi tubuh bertengger pada kayu dengan kedua mata terbuka.

b. Istirahat, adalah aktivitas yang dilakukan dengan posisi diam sedangkan kedua mata memperhatikan setiap gerakan benda di luar kandang.

c. Berjemur, adalah aktivitas yang dilakukan pada pagi hari dengan cara merentangkan kaki dan sayap menghadap matahari pagi.

3. Perilaku ingestif, dengan aktivitas:

a. Makan, adalah aktivitas ingestif yang dilakukan dengan cara mengambil dan menghancurkan makanan menggunakan paruh dan lidah.

b. Minum, adalah aktivitas yang dilakukan dengan cara mencelupkan paruh ke dalam air lalu menengadahkan paruh.

c. Membersihkan paruh, adalah aktivitas yang dilakukan dengan cara membersihkan diri atau pasangannya menggunakan paruh dan kaki.

4. Perilaku kawin, dengan aktivitas:

a. Mendekati betina, adalah aktivitas yang dilakukan hanya oleh burung jantan dengan cara berdekatan pada saat bertengger untuk mencari perhatian seekor betina. 
b. Menyelisik, adalah aktivitas yang dilakukan terhadap individu lain atau sejenis, menggunakan paruh dengan cara mengelus, pura-pura menggigit, dan mengendus.

c. Bercumbu, adalah aktivitas yang dilakukan terhadap pasangan dengan cara mencium dan memasukkan paruh pada paruh lawan jenis.

\section{Analisis Data}

Analisis data dilakukan menggunakan rumus (Sudjana,1992), sebagai berikut:

\begin{tabular}{|c|c|c|}
\hline $\begin{array}{l}\text { Ratarata } \\
\text { perilaku }\end{array}$ & $\begin{array}{l}\text { Jumlah aktivitas/j } \\
\text { kandang/jumlah b } \\
\text { Jumlah hari }\end{array}$ & $\begin{array}{l}\text { umlah } \\
\text { urung } \\
\end{array}$ \\
\hline $\begin{array}{l}\text { Frekuensi } \\
\text { relatif }\end{array}$ & $\begin{array}{c}\text { Jumlah frekuensi } \\
\text { suatu aktivitas } \\
\begin{array}{c}\text { Jumlah frekuensi } \\
\text { seluruhnya }\end{array}\end{array}$ & x 100\% \\
\hline $\begin{array}{l}\text { Waktu } \\
\text { relatif }\end{array}$ & $\begin{array}{c}\begin{array}{c}\text { Jumlah waktu } \\
\text { suatu aktivitas }\end{array} \\
\text { Jumlah waktu } \\
\text { seluruhnya }\end{array}$ & x 100\% \\
\hline
\end{tabular}

\section{HASIL DAN PEMBAHASAN}

\section{A. Proses Adaptasi}

Hasil pengamatan menunjukkan burung bayan sumba hasil penangkaran Oilsonbai yang akan dikembangkan di KHDTK Hambala, perlu menjalani masa adaptasi yang cukup lama. Hal ini karena perjalanan laut selama sehari semalam dengan kondisi yang cukup ramai serta kurungan atau sangkar kawat yang kecil dan sempit. Terlihat burung sangat lemah dan aktivitas yang dilakukan lebih banyak diam serta nafsu makan berkurang. Oleh karena itu, burung bayan tersebut diberi obat anti stres melalui air minum untuk memulihkan kondisi. Metode pendekatan untuk membiasakan burung dengan lingkungan yang baru perlu dikembangkan sesuai dengan tingkat stresnya melalui cara pemberian pakan dan pendekatan oleh petugas.
Pada saat terbang, burung mengeluarkan suara yang sangat keras dan melengking. Dari semua jenis burung paruh bengkok, burung bayan bersuara dan berteriak paling keras terutama apabila ada dalam lingkungan baru. Hal ini berkaitan dengan sifat menyelidiki pada burung yang ditempatkan pada lingkungan baru. Memberi kesempatan pada burung untuk menyelidiki keadaan lingkungan sekitar, akan lebih memudahkan proses adaptasi burung. Perilaku menyelidik dapat menjadi karakteristik penting untuk memudahkan burung mengetahui kondisi bahaya.

Namun secara umum apabila dibandingkan dengan burung yang ditangkap dari alam, burung bayan hasil penangkaran lebih mudah beradaptasi dengan lingkungan baru walaupun sebagai satwaliar, sifat liar masih belum sepenuhnya hilang. Mulyana (1995) mengatakan, kondisi fisik dan keliaran induk burung turut mempengaruhi persentase mortalitas induk. Induk yang berasal dari alam masih liar, lebih mudah stres dan mudah terserang penyakit. Hal ini terbukti dari awal penangkaran burung bayan sumba dari alam yang dilakukan di Oilsonbai tahun 1994, telah terjadi kematian sebanyak 50\% dari 24 ekor induk (12 jantan dan 12 betina). Tetapi tidak demikian dengan burung hasil penangkaran, atau yang pernah dipelihara masyarakat, terlihat lebih jinak karena telah beradaptasi dengan lingkungan.

Proses adaptasi burung hingga menjadi jinak memerlukan tahapan yang panjang untuk bersosialisasi dengan lingkungan (perawat/keeper, pakan, kandang bahkan sesama burung yang berada dalam penangkaran). Proses adaptasi terhadap lingkungan diawali dengan pemberian pakan. Pemberian pakan dilakukan dua kali sehari, sehingga dengan demikian semakin lama burung-burung tersebut terbiasa menerima kehadiran manusia di dalam kandang. Dalam pemberian pakan tersebut dimungkinkan tangan perawat masuk ke kandang dan bersentuhan dengan burung tersebut. Hal ini akan 
mempengaruhi perilaku agonistik individu burung dari yang semula agresif menjadi jinak. Aktivitas lain seperti saat membersihkan kandang dan monitoring kesehatan akan membantu mempercepat proses adaptasi tersebut. Demikian juga dengan jenis pakan yang belum biasa dikonsumsi burung, memerlukan proses untuk adaptasi sehingga semakin lama burung akan menjadi terbiasa dan terlihat lebih jinak.

\section{B. Perilaku}

Perilaku satwa adalah semua gerakan atau perubahan gerak, termasuk perubahan dari bergerak ke tidak bergerak (Tanudimadja, 1978). Perilaku akibat rangsangan terdapat pada hampir semua individu dalam satu spesies, tetapi kadangkadang ada perilaku yang tidak didasari oleh pengalaman terlebih dahulu, yaitu perilaku bawaan.
Sejak tiba di lokasi penangkaran Hambala, ada empat jenis perilaku utama yang dilakukan oleh burung bayan sumba, yakni perilaku bergerak, diam, ingestif, dan kawin. Burung bayan sering melakukan empat jenis perilaku utama tersebut untuk hidup, makan, bersosialisasi, dan berkembangbiak.

\section{Bergerak}

Burung merupakan satwa yang paling aktif terutama pada lingkungan yang baru, di mana sering terlihat melakukan aktivitas bergerak dengan cara memanjat, melompat, berjalan, terbang, berteriak, dan berkelahi. Oleh karena itu, aktivitas tersebut menjadi parameter dalam pengamatan perilaku pada burung bayan yang berada di penangkaran. Tabel 1 menampilkan jenis perilaku dan aktivitas burung bayan sumba di penangkaran Oilsonbai, NTT hasil penelitian Ringa (2000) sebagai pembanding dalam penelitian ini.

Tabel (Table) 1. Perilaku burung bayan sumba di penangkaran (Behaviour of bayan sumba bird in captive breeding)

\begin{tabular}{|c|c|c|c|c|c|c|}
\hline \multirow[b]{2}{*}{ No. } & \multirow[b]{2}{*}{$\begin{array}{c}\text { Perilaku } \\
\text { (Behaviour) }\end{array}$} & \multirow[b]{2}{*}{ Aktivitas (Activity) } & \multicolumn{2}{|c|}{$\begin{array}{l}\text { Hasil penelitian } 2000 \\
\text { (Result of the } 2000 \\
\text { research)* }\end{array}$} & \multicolumn{2}{|c|}{$\begin{array}{c}\text { Hasil penelitian } 2003 \\
\text { (Result of the } 2003 \\
\text { research)** }\end{array}$} \\
\hline & & & $\begin{array}{l}\text { Frekuensi } \\
\quad \text { (kali)/ } \\
\text { Frequency } \\
\text { (time) }\end{array}$ & $\begin{array}{l}\text { Waktu } \\
\text { (menit)/ } \\
\text { Time } \\
\text { (minute) }\end{array}$ & $\begin{array}{l}\text { Frekuensi } \\
\quad \text { (kali)/ } \\
\text { Frequency } \\
\text { (time) }\end{array}$ & $\begin{array}{c}\text { Waktu } \\
\text { (menit)/ } \\
\text { Time } \\
\text { (minute) }\end{array}$ \\
\hline \multirow[t]{5}{*}{1.} & Bergerak (Moving) & Terbang (Flying) & 7,5 & 44,5 & 7,6 & 5,8 \\
\hline & & Menggelantung (Hanging) & 5,7 & 31,7 & 2,5 & 6,6 \\
\hline & & Berjalan (Walking) & 59,3 & 355,7 & 2,4 & 3,6 \\
\hline & & Berkelahi (Fighting) & 2,5 & 16,1 & 0,04 & 2,5 \\
\hline & Jumlah (Sum) & & 75,0 & 448,0 & 12,5 & 18,5 \\
\hline \multirow[t]{4}{*}{2.} & Diam (Idle) & Bertengger (Perching) & 6,2 & 37,25 & 12,2 & 242,4 \\
\hline & & Beristrahat (Resting) & 4,7 & 46,03 & 4,2 & 5,8 \\
\hline & & Berjemur (Drying) & 14,9 & 34,6 & 0,1 & 5,9 \\
\hline & Jumlah (Sum) & & 25,8 & 117,9 & 16,5 & 254,1 \\
\hline \multirow[t]{4}{*}{3.} & Ingestif (Ingestive) & Makan (Eating) & 8,3 & 54,1 & 5,03 & 51,5 \\
\hline & & Minum (Drinking) & 0,4 & 15,4 & 1,3 & 1,6 \\
\hline & & $\begin{array}{l}\text { Membersihkan paruh } \\
\text { (Cleaning up of beak) }\end{array}$ & 4,7 & 12,1 & 0,1 & 2,7 \\
\hline & Jumlah (Sum) & & 13,4 & 81,6 & 6,4 & 55,8 \\
\hline \multirow[t]{4}{*}{4.} & Kawin (Mating) & Menyelisik (Delouse) & 9,4 & 56,7 & 1,4 & 28,6 \\
\hline & & Bercumbu (Flirting) & - & - & 0,4 & 0,2 \\
\hline & & $\begin{array}{l}\text { Mendekati betina (Approach } \\
\text { female) }\end{array}$ & - & - & 0,1 & 0,2 \\
\hline & Jumlah (Sum) & & 9,4 & 56,7 & 1,9 & 29,0 \\
\hline \multicolumn{3}{|c|}{ Total seluruh (Total) } & 123,6 & 704,2 & 37,3 & 357,4 \\
\hline \multicolumn{3}{|c|}{ Rata-rata (Average) } & 30,9 & 176,05 & 9,3 & 89,35 \\
\hline
\end{tabular}




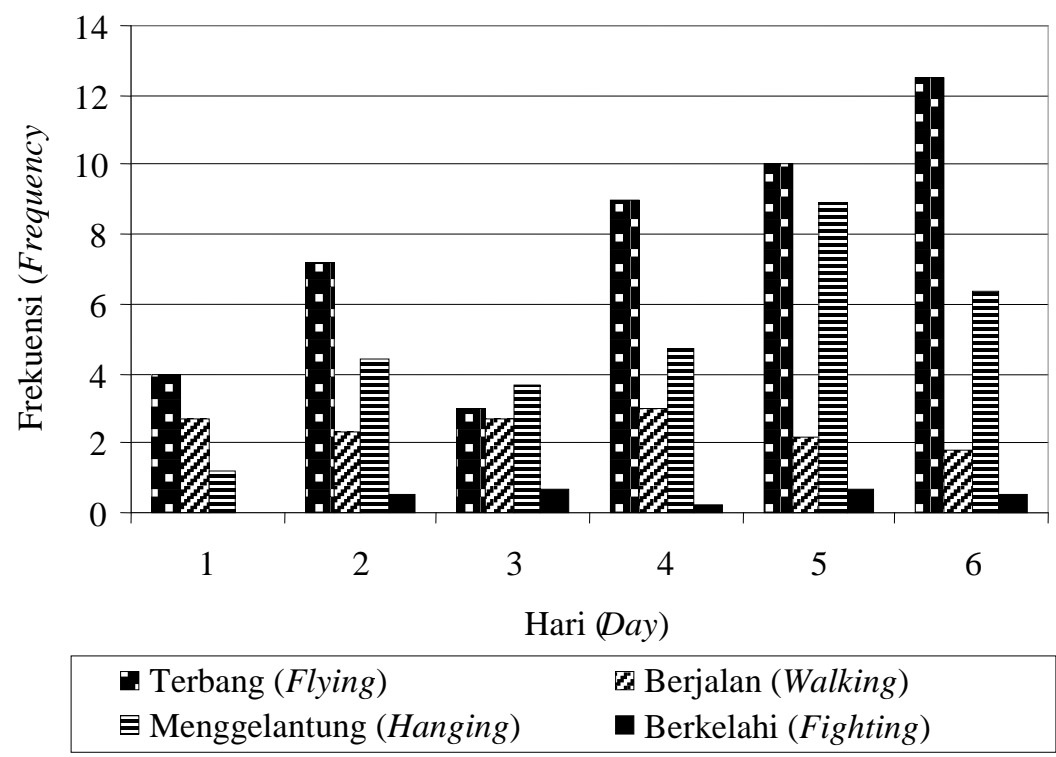

Gambar (Figure) 1. Rata-rata frekuensi aktivitas bergerak pada bayan sumba di Hambala (Average of moving behaviour frequency of the bayan sumba bird in Hambala)

Perilaku bergerak pada burung bayan sumba di penangkaran Hambala ditunjukkan oleh rata-rata frekuensi aktivitas terbang yang tinggi, kemudian diikuti oleh aktivitas menggelantung, berjalan, dan yang terendah aktivitas berkelahi (Gambar 1).

Terlihat pada Gambar 1, rata-rata frekuensi pada aktivitas terbang yang dilakukan oleh burung bayan di penangkaran Hambala sebesar 7,6 kali atau 60,8\% dengan waktu 5,8 menit. Jumlah frekuensi ini tidak terlalu jauh berbeda dengan hasil penelitian Ringa (2000) di mana aktivitas terbang pada burung bayan di penangkaran Oilsonbai sebesar 7,5 kali atau 10,04\%. Tingginya aktivitas terbang pada burung bayan sumba di Hambala disebabkan burung masih dalam tahap menyelidiki keadaan sekitar sehingga apabila ada gerakan yang mencurigakan, secara otomatis burung langsung terbang sambil mengeluarkan suara keras. Namun kemampuan terbang pada burung dalam kandang penangkaran mempunyai keterbatasan karena luasan kandang yang terbatas, sehingga tidak memungkinkan bagi seekor burung melakukan aktivitas terbang dalam waktu lama.

Aktivitas berjalan termasuk dalam perilaku bergerak yang dilakukan untuk memperoleh pakan, air, dan pasangan. Rata-rata frekuensi berjalan yang dilakukan adalah sebesar 2,4 kali (19,2\%) dengan waktu 3,6 menit. Jumlah ini sangat kecil dibandingkan dengan frekuensi berjalan yang dilakukan burung bayan di penangkaran Oilsonbai, yakni sebesar 59,3 kali atau 79,1\% (Ringa, 2000). Rendahnya aktivitas ini pada burung bayan di Hambala karena burung memerlukan masa adaptasi dengan lingkungan sekitar.

Burung yang baru datang sangat waspada terhadap lingkungan di mana sekalisekali burung mengangkat kepala untuk mengawasi lingkungan sekitar. Hal ini berkaitan dengan sifat investigasi atau menyelidiki yang dimiliki satwa terhadap lingkungan yang baru adalah sangat tinggi (Wodzicka-Tomaszewska et al., 1991). Sifat menyelidiki dimaksudkan agar cepat menyesuaikan diri dengan perubahan lingkungan sekitar sehingga dapat mempertahankan kehidupan selanjutnya. Di samping itu, pendengaran burung cukup tajam sehingga selalu waspada terhadap lingkungan.

Aktivitas menggelantung dilakukan lebih banyak pada pagi hari dengan ratarata frekuensi sebesar 2,5 kali (20,0\%) selama 6,6 menit. Berbeda dengan hasil penelitian Ringa (2000) di Oilsonbai yang 
menyatakan bahwa rata-rata frekuensi aktivitas menggelantung sebesar 13,25 kali pada pagi hari, siang hari sebesar 10,25 kali, dan sore hari 10,7 kali selama 31,7 menit. Perbedaan ini berhubungan dengan proses adaptasi yang dilakukan pada lingkungan baru. Burung bayan pada lingkungan baru, akan belajar beradaptasi walaupun selalu disertai dengan investigasi terhadap semua gerakan manusia. Hasil pengamatan menunjukkan burung bayan yang sering melakukan aktivitas menggelantung adalah burung jantan karena lebih mudah beradaptasi dengan lingkungan dibanding betina. Burung betina lebih sensitif terhadap gerakan-gerakan yang didengar dan dilihatnya sehingga aktivitasnya menjadi terganggu. Aktivitas menggelantung dilakukan sambil menggigit kawat atau mencengkeram karena bentuk paruhnya yang bengkok dan kuat, sehingga burung mudah berpindah tempat menggunakan kaki. Perpindahan dilakukan dengan cara menggaet atau menggigit kawat yang merupakan suatu kekuatan untuk menahan tubuh sehingga kakinya dapat berpindah tempat.

Aktivitas berkelahi pada burung bayan sumba di penangkaran Hambala, sangat kecil. Gambar 1 menunjukkan aktivitas berkelahi memiliki frekuensi paling rendah yaitu sebesar 0,04 kali $(0,3 \%)$ selama 2,5 menit, sedangkan hasil penelitian Ringa (2000) sebesar 2,5 kali selama 16,1 menit. Hal ini karena burung masih beradaptasi dengan lingkungan sehingga sangat kecil sekali untuk melakukan aktivitas berkelahi. Aktivitas berkelahi lebih banyak dilakukan oleh burung bayan jantan dibandingkan betina. Perkelahian yang terjadi bukan merupakan perkelahian yang aktual atau sesungguhnya seperti yang sering terjadi di alam antara burung jantan dan jantan lain dalam mencari pasangan betina.

Hasil analisis menunjukkan frekuensi dari perilaku bergerak pada burung bayan sumba di KHDTK Hambala sebanyak 12,5 kali dalam waktu 18,5 menit, sedangkan hasil penelitian Ringa (2000) menyatakan frekuensi perilaku bergerak pada burung bayan sumba di penangkaran Oilsonbai mencapai 75,0 kali dalam waktu 448 menit. Hal ini menunjukkan bahwa burung bayan di Hambala masih merasa asing sehingga lebih banyak berdiam diri sambil mengawasi lingkungan sekitar.

\section{Perilaku Diam}

Perilaku diam yang dilakukan oleh burung bayan di penangkaran Hambala terdiri dari tiga jenis aktivitas yaitu bertengger, berjemur, dan istrahat. Burung yang baru datang, umumnya lebih banyak beraktivitas diam sambil mengawasi keadaan sekitar. Oleh karena itu pada saat bertengger, kedua matanya terbuka sambil mengangkat kepala lalu mengarahkan mata dan telinga ke segala arah.

Perilaku diam yang dilakukan burung bayan di Hambala mencapai frekuensi sebesar 16,5 kali dengan durasi waktu 254,1 menit sedangkan frekuensi perilaku diam pada burung bayan di Oilsonbai sebanyak 25,8 kali dengan waktu 117,9 menit (Ringa, 2000). Tingginya waktu dalam perilaku diam pada burung bayan di Hambala disebabkan burung masih ingin menyelidiki lingkungan baru sehingga perilaku diam dilakukan dalam waktu yang lebih lama dibandingkan dengan burung bayan yang sudah lama berada di penangkaran Oilsonbai.

Dari data yang diperoleh, ternyata frekuensi perilaku diam tertinggi dicapai oleh aktivitas bertengger sebesar 12,2 kali dalam waktu 242,4 menit lebih tinggi dibandingkan dengan hasil penelitian Ringa (2000) yakni sebesar 6,2 kali dalam waktu 37,25 menit. Aktivitas bertengger pada burung bayan di Hambala lebih banyak dilakukan oleh burung jantan dibandingkan burung betina. Aktivitas ini sering terjadi apabila petugas memasuki kandang, yang diawali dengan teriakan yang sangat keras lalu bertengger di atas kawat dan diam selama merasa ada gangguan. Hal ini lebih banyak dilakukan oleh burung jantan karena umumnya burung jan- 
tan mempunyai sifat melindungi, lebih agresif, dan lebih berani terhadap gangguan dibandingkan dengan burung betina. Sifat melindungi ini sering terlihat di penangkaran Oilsonbai, di mana apabila burung betina sedang di dalam nest box (kotak sarang) untuk bertelur, mengeram, atau mengasuh anaknya, maka burung jantan berperan menjaga kotak sekaligus melindungi dan memberi makan induk betina dan anaknya, sedangkan induk betina tetap di dalam nest box hingga anaknya bisa terbang sendiri (Takandjandji, 2005). Burung bayan mempunyai jari kaki yang sangat kuat sehingga dapat bertengger atau mencengkeram kawat dengan baik. Hal ini terlihat apabila burung ditangkap, akan sulit dilepaskan dari kawat atau tenggeran karena jari-jarinya mencengkeram sangat kuat.

Aktivitas beristirahat dilakukan dengan posisi tubuh bertengger, bagian ventral merunduk, kedua kaki mencengkram erat pada kayu atau tenggeran, dan kedua mata terpejam. Sering terlihat burung bayan melakukan aktivitas istirahat dengan cara mengangkat satu kaki, sementara kaki yang lain ditarik ke dalam bulu-bulu tubuhnya. Saat menjalankan aktivitas ini, bulu tubuh agak terbuka dan biasanya kepala direbahkan ke belakang, disembunyikan di antara bulu-bulu punggung dengan mata tertutup. Aktivitas istirahat dilakukan sambil memejamkan kedua mata dan lebih banyak dilakukan pada siang hari di mana suhu udara cukup panas dengan rata-rata $34^{\circ} \mathrm{C}$. Frekuensi aktivitas istirahat pada burung bayan di Hambala sebesar 4,2 kali selama 5,8 menit sementara di Oilsonbai sebesar 4,7 kali selama 46,03 menit.

Aktivitas berjemur dilakukan pada setiap pagi hari dengan cara mengangkat sebelah kaki sambil menghadap matahari. Kemungkinan, hal ini dilakukan untuk mendapatkan sinar matahari pada pagi hari dan kebutuhan vitamin D untuk pertumbuhan tulang. Pada saat melakukan aktivitas berjemur, terlihat burung sering merentangkan sayap dan kaki yang didu- ga untuk melemaskan otot-otot karena selama dalam perjalanan (transportasi laut) menggunakan sangkar kecil. Aktivitas ini dilakukan secara diam, walaupun kadangkadang terdengar suara seperti bergumam. Berbeda dengan burung-burung di alam, apabila melakukan aktivitas berjemur kedengarannya sangat ribut. Namun demikian keributan tersebut tergantung jumlah burung yang melakukan aktivitas. Seperti di Oilsonbai, aktivitas ini dilakukan oleh beberapa pasang burung sehingga terdengar sangat ramai. Aktivitas berjemur merupakan aktivitas terendah yang dilakukan dalam perilaku diam yakni sebesar 0,1 kali selama 5,9 menit (Gambar 2), sedangkan frekuensi aktivitas berjemur pada hasil penelitian Ringa (2000) sangat tinggi sebesar 14,9 kali selama 34,6 menit.

Hasil analisis menunjukkan frekuensi rata-rata perilaku diam dengan aktivitas bertengger yang paling banyak dilakukan kemudian diikuti oleh istirahat dan berjemur. Hal ini disebabkan burung bayan belum terbiasa dengan lingkungan sekitar sehingga perlu adaptasi. Di samping itu, suhu di lokasi penangkaran Hambala sangat panas $\left(35^{\circ} \mathrm{C}\right)$ sehingga burung lebih banyak melakukan perilaku diam dengan bertengger.

\section{Perilaku Ingestif}

Pakan merupakan salah satu faktor penting yang menentukan keberhasilan upaya penangkaran burung. Perilaku ingestif meliputi aktivitas makan, minum, dan membersihkan paruh setelah melakukan aktivitas makan. Aktivitas makan pada burung bayan sangat menarik untuk diperhatikan. Pada waktu makan, paruh burung terbuka dan ujung lidahnya yang berbentuk sikat menarik makanan, kemudian lidahnya dimasukkan atau ditarik kembali ke dalam paruh. Di dalam proses makan, ujung lidahnya berperan sangat penting. Makanan yang diberikan, diambil oleh burung kemudian dihancurkan menggunakan paruh dan lidah, kemudian ditelan. Pada burung bayan di 


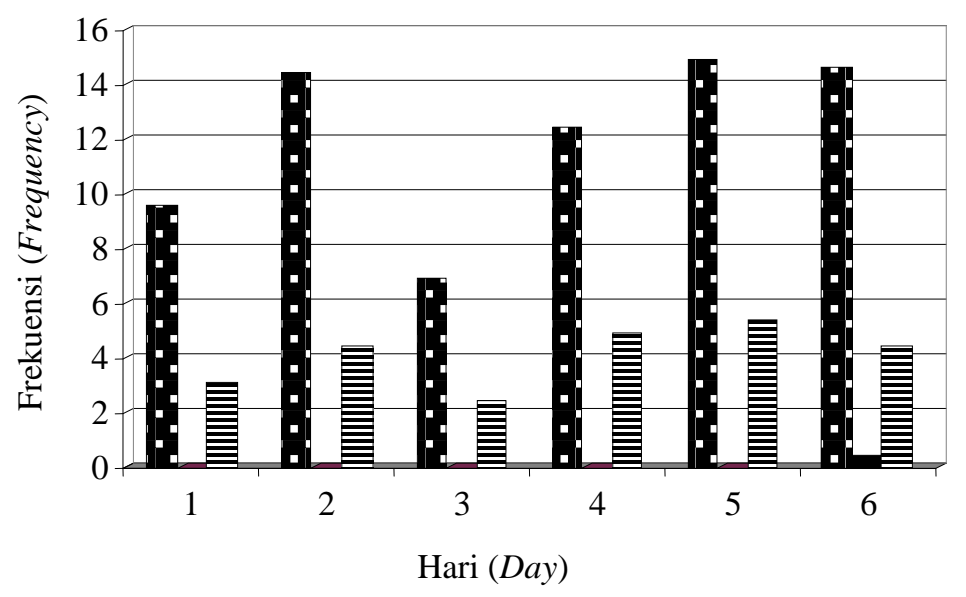

Bertengger (Perching) $\quad$ Berjemur (Drying) $\quad$ : Istirahat (Resting)

Gambar (Figure) 2. Rata-rata frekuensi perilaku diam pada bayan sumba di Hambala (Average of idle behaviour frequency of bayan sumba bird in Hambala)

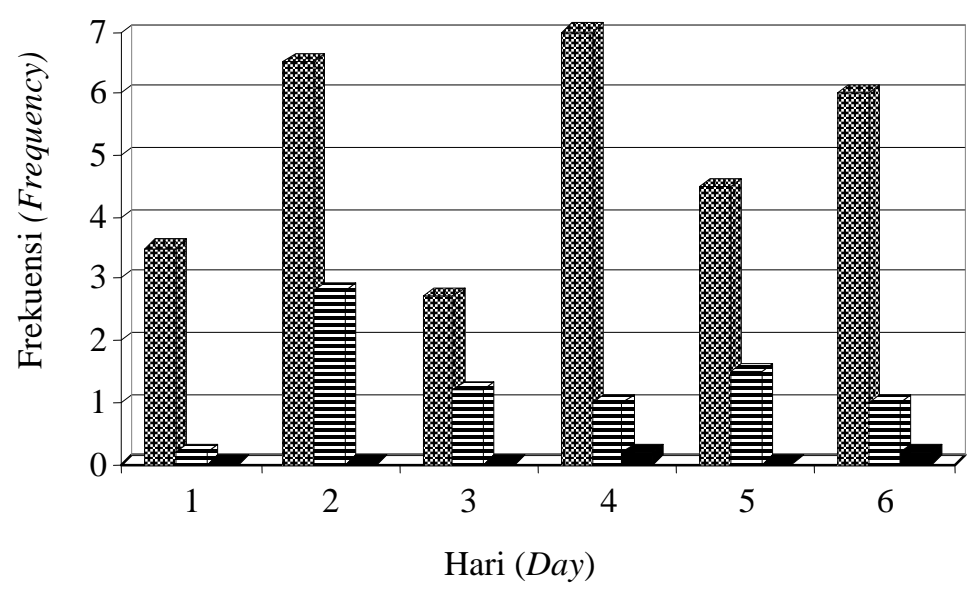

Makan (Eating) $\quad$ Minum (Drinking) \ Membersihkan (Cleaning)

Gambar (Figure) 3. Rata-rata frekuensi perilaku ingestif pada bayan sumba di Hambala (Average of ingestive behaviour frequency of bayan sumba bird in Hambala)

Oilsonbai, sering terlihat burung jantan menyuapi burung betina dengan cara memuntahkan makanan ke dalam mulut betina.

Hasil analisis menunjukkan bahwa frekuensi perilaku ingestif pada burung bayan di Hambala mencapai 6,4 kali dalam durasi waktu 55,8 menit. Sementara hasil penelitian Ringa (2000) menyatakan frekuensi perilaku ingestif pada burung bayan di Oilsonbai sebesar 13,4 kali selama 81,6 menit. Perbedaan ini disebabkan burung bayan di Hambala belum ber- adaptasi dengan lingkungan sehingga belum berani melakukan aktivitas makan dalam jumlah banyak, di samping kondisi lingkungan yang panas $\left(35^{\circ} \mathrm{C}\right)$ dapat mempengaruhi konsumsi pakan.

Secara rinci dapat dikatakan bahwa aktivitas makan merupakan aktivitas tertinggi pada perilaku ingestif, dengan frekuensi sebesar 5,03 kali atau 78,6\% selama 51,5 menit. Berbeda dengan burung bayan di Oilsonbai yang melakukan aktivitas makan sebesar 8,3 kali atau 61,9\% selama 54,1 menit. Demikian pula rata- 
rata waktu yang digunakan dalam beraktivitas makan di Hambala lebih tinggi dibandingkan aktivitas lainnya.

Terdapat perbedaan yang tidak terlalu jauh dalam aktivitas makan pada burung jantan dan betina, sedangkan antara burung jantan dan betina menunjukkan frekuensi dan waktu yang sama dalam mengkonsumsi pakan. Sifat agonistik seperti bertengkar dan berkelahi dalam perebutan makanan tidak terjadi pada burung bayan di dalam penangkaran karena pakan cukup terpenuhi, baik kualitas maupun kuantitas.

Frekuensi aktivitas makan lebih banyak dipengaruhi oleh suhu di sekitar kandang di mana burung lebih banyak melakukan aktivitas makan pada pagi dan sore hari sesuai dengan jadwal pemberian pakan. Bagi burung di penangkaran tidak ada pilihan dalam hal pakan karena semua tergantung pada petugas. Oleh karena itu, petugas harus menyiapkan pakan yang sesuai dengan kebutuhannya, baik kualitas maupun kuantitasnya dan mempunyai nilai gizi yang tinggi. Burung akan mengkonsumsi pakan yang secara alamiah biasa dimakan, dibandingkan dengan pakan yang terbuat dari produk sampingan yang bernilai gizi tinggi atau pakan suplemen. Tingkat konsumsi pada burung akan lebih tinggi apabila dalam keadaan lapar karena makan merupakan kebutuhan paling penting dalam perkembangbiakan makhluk hidup.

Aktivitas minum pada burung bayan dilakukan dengan cara menundukkan kepala, paruh dibuka lebar, dan ujung lidah menyentuh air. Ujung lidah (papilla) mengambil air, lalu ditarik masuk ke dalam mulut. Proses ini terus berlangsung sampai rasa hausnya hilang. Frekuensi aktivitas minum yang dilakukan burung bayan di Hambala sebesar 1,3 kali (20,3\%) dalam durasi waktu 1,6 menit, berbeda dengan burung bayan di Oilsonbai sebesar 0,4 kali atau 2,9\% selama 15,4 menit (Ringa, 2000). Perbedaan ini bergantung pada jenis pakan yang dikonsumsi dan suhu atau kelembaban di se- kitar kandang. Suhu di Hambala mencapai rata-rata $35^{\circ} \mathrm{C}$ sedangkan di Oilsonbai $30^{\circ} \mathrm{C}$. Pemberian air minum selalu dalam keadaan bersih dan diganti setiap hari. Air minum yang diberikan pada burung bayan dicampur dengan vitamin untuk mengurangi stres, mudah beradaptasi, dan menambah nafsu makan.

Aktivitas membersihkan paruh dilakukan apabila telah selesai melakukan aktivitas makan. Paruhnya dibersihkan dari kotoran atau sisa pakan yang menempel dengan cara menggesek-gesekan paruh pada kayu tenggeran, tetapi kadang-kadang burung mengangkat salah satu kakinya kemudian paruh dibersihkan menggunakan jari kaki. Hasil analisis diperoleh bahwa rata-rata frekuensi pada aktivitas membersihkan paruh adalah yang terendah dalam perilaku ingestif. Frekuensi aktivitas membersihkan paruh pada burung bayan di Hambala sebesar 0,1 kali atau $1,6 \%$ selama 2,7 menit sementara di Oilsonbai sebesar 4,7 kali dengan persentase sebesar 35,1\% selama 12,1 menit. Membersihkan paruh pada burung bayan kadang-kadang dilakukan pada saat minum dan tergantung pula pada jenis pakan yang dikonsumsi.

\section{Perilaku Kawin}

Perilaku kawin pada burung bayan sumba di penangkaran Hambala meliputi aktivitas mendekati betina bagi yang jantan, menyelisik, dan bercumbu. Dalam kehidupan burung bayan, terlihat bahwa sistem perkawinan yang dilakukan adalah monogami. Hal ini sesuai dengan pernyataan Lock (1966) dalam Saka dan Lepa (1994) bahwa 92\% dari jenis burung melakukan sistem perkawinan secara monogami. Selanjutnya dikatakan, umumnya jenis burung yang mempunyai sistem perkawinan monogami cenderung memilih pasangan yang permanen namun selalu terbuka peluang untuk dapat mengadakan kopulasi atau perkawinan dengan lebih dari satu induk betina sebagai pasangan tidak tetap. 
Hasil analisis menunjukkan frekuensi perilaku kawin pada burung bayan di Hambala sebesar 1,9 kali dalam waktu 29,0 menit. Hasil penelitian Ringa (2000) menyatakan frekuensi perilaku kawin pada burung bayan di Oilsonbai sebesar 9,4 kali dalam waktu 56,7 menit.

Aktivitas mendekati betina merupakan bagian dari perilaku kawin karena sebelum melakukan perkawinan, terlebih dahulu burung jantan melakukan pendekatan dengan betina sambil menganggukanggukkan kepala dan mengeluarkan suara. Frekuensi aktivitas ini dilakukan sangat kecil yakni 0,1 kali atau 5,3\% dalam waktu 0,2 menit padahal burung tersebut merupakan pasangan sejak di penangkaran Oilsonbai dan sudah saling mengenal satu sama lain. Biasanya apabila sudah sejodoh, pasangan selalu ingin berdekatan, namun karena burung ada di lingkungan yang baru sehingga pendekatan terhadap betina kurang berani dilakukan.

Aktivitas menyelisik dilakukan setelah terjadi pendekatan terhadap betina. Aktivitas ini dilakukan dengan cara saling membersihkan bulu-bulu kepala dan leher menggunakan paruh, dengan frekuensi sebanyak 1,4 kali atau 73,7\% selama 28,6 menit. Aktivitas menyelisik merupakan aktivitas tertinggi yang dilakukan oleh burung bayan di Hambala dalam perilaku kawin. Hasil penelitian Ringa (2000) pada burung bayan di Oilsonbai jauh lebih tinggi yakni sebanyak 9,4 kali pada jam 10.00-12.00 atau setelah makan. Perbedaan ini karena burung bayan di Hambala baru datang dan masih menyesuaikan diri dengan lingkungan sehingga aktivitas belum banyak dilakukan.

Aktivitas bercumbu merupakan tahapan akhir dari perilaku kawin pada burung bayan di Hambala di mana terlihat burung jantan menyentuh dan memasukkan sebagian paruhnya ke paruh sang betina. Aktivitas ini dilakukan sebanyak 0,4 kali atau $21,05 \%$ dalam waktu 0,2 menit. Berbeda dengan burung bayan di Oilsonbai yang tidak melakukan aktivitas bercumbu tetapi langsung melakukan aktivitas kawin, dan kemudian bertelur. Hal ini karena burung bayan di Oilsonbai sudah beradaptasi dengan lingkungan sekitar sehingga mudah dalam melakukan perkawinan.

Jumlah frekuensi dari empat jenis perilaku utama yang dilakukan burung bayan di KHDTK Hambala sebesar 37,3 kali dengan rata-rata 9,3 kali dalam durasi waktu 89,35 menit. Sementara total frekuensi yang dilakukan burung bayan di Oilsonbai sebesar 123,6 kali dengan ratarata 30,9 kali dalam durasi waktu 176,05 menit (Ringa, 2000).

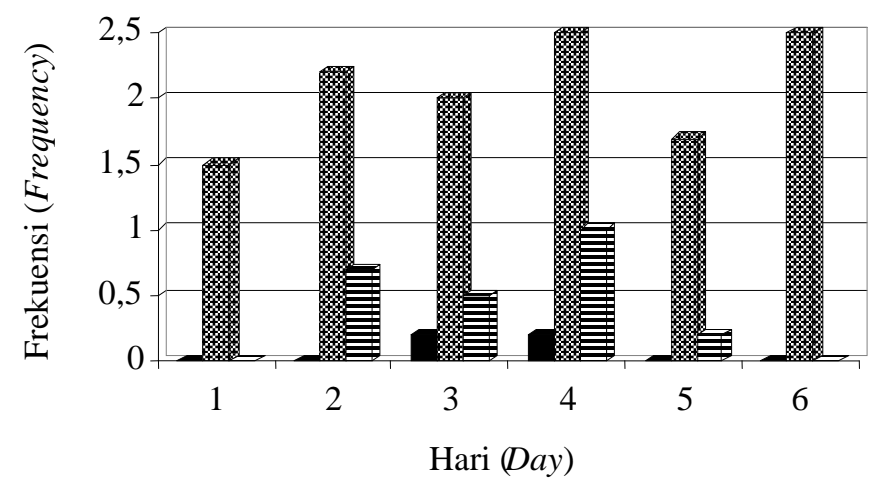

Mendekati (Approach) Menyelisik (Delouse) $\equiv$ Bercumbu

Gambar (Figure) 4. Rata-rata frekuensi perilaku kawin pada bayan sumba di Hambala (Average of mating behaviour frequency of bayan sumba bird in Hambala) 
Rendahnya frekuensi perilaku yang dilakukan burung bayan di Hambala disebabkan oleh beberapa faktor, antara lain burung belum beradaptasi dengan lingkungan, lamanya perjalanan yang ditempuh, sempitnya sangkar yang digunakan selama dalam perjalanan, ramainya orang selama dalam perjalanan dan di lokasi penangkaran, serta tingginya suhu udara di lokasi penangkaran. Hal ini dapat mempengaruhi kuantitas suatu aktivitas yang dilakukan.

\section{KESIMPULAN DAN SARAN}

\section{A. Kesimpulan}

1. Burung bayan sumba di dalam penangkaran di KHDTK Hambala melakukan empat macam perilaku utama yakni perilaku bergerak termasuk di dalamnya aktivitas berjalan, terbang, menggelantung, dan berkelahi; perila$\mathrm{ku}$ diam termasuk aktivitas bertengger, istrahat, dan berjemur; perilaku ingestif termasuk aktivitas makan, minum, dan membersihkan paruh; serta perilaku kawin meliputi aktivitas mendekati betina, menyelisik, dan bercumbu.

2. Perilaku bergerak dengan aktivitas terbang mempunyai frekuensi tertinggi yaitu 12,5 kali selama 18,5 menit terdiri dari aktivitas terbang 7,6 kali atau $60,8 \%$ selama 5,8 menit; berjalan 2,4 kali atau 19,2\% selama 3,6 menit; menggelantung 2,5 kali atau 20,0\% selama 6,6 menit; dan terendah aktivitas berkelahi sebanyak 0,04 kali atau $0,3 \%$ selama 2,5 menit.

3. Perilaku diam tertinggi dicapai dalam aktivitas bertengger sebanyak 12,2 kali atau 73,9\% selama 242,4 menit; aktivitas beristrahat sebesar 4,2 kali atau 25,4\% dalam waktu 5,8 menit; dan terendah aktivitas berjemur sebanyak 0,1 kali atau 0,6\% selama 5,9 menit.

4. Perilaku ingestif dengan aktivitas makan mempunyai frekuensi tertinggi 368 sebanyak 5,03 kali atau 78,6\% dalam waktu 51,5 menit; aktivitas minum sebesar 1,3 kali atau 20,3\% selama 1,6 menit; dan aktivitas membersihkan paruh sebanyak 0,1 kali atau $1,6 \%$ selama 2,7 menit.

5. Perilaku kawin dengan aktivitas menyelisik mempunyai frekuensi tertinggi yakni sebesar 1,4 kali atau 73,7\% selama 28,6 menit; aktivitas bercumbu sebesar 0,4 kali atau $21,05 \%$ selama 0,2 menit; dan aktivitas mendekati betina sebanyak 0,1 kali atau 5,3\% selama 0,2 menit.

\section{B. Saran}

1. Burung yang akan ditangkarkan sebaiknya merupakan hasil penangkaran, bukan yang berasal dari alam sehingga lebih cepat beradaptasi dengan lingkungan.

2. Burung yang akan direlokasi sebaiknya diperhatikan kualitas dan kuantitas pakan, minum, dan kenyamanan selama dalam perjalanan sehingga tidak menyebabkan stres, terutama apabila perjalanan tersebut cukup lama. Sangkar yang digunakan sebaiknya tidak terlalu kecil atau sempit dengan ukuran yang ideal lebar 70-90 cm, tinggi $70-150 \mathrm{~cm}$, panjang $80-180$ $\mathrm{cm}$, dan tinggi kaki $60 \mathrm{~cm}$ sehingga burung bisa bebas bergerak, ditutup dengan kain berwarna gelap untuk mengurangi stres, namun sirkulasi udara perlu diperhatikan.

3. Lingkungan sekitar lokasi penangkaran sebaiknya berbentuk alami sehingga burung merasa seperti di habitat alam. Penanaman pohon pelindung (cover) di sekitar kandang akan berfungsi untuk menahan angin dan menambah keteduhan.

4. Penangkaran burung akan berhasil apabila ditunjang oleh sumberdaya manusia yang profesional dan mempunyai motivasi untuk menangkarkan, dalam arti ikut bertanggungjawab terhadap kelestariannya dan mempunyai 
sifat sabar, rajin, tekun, disiplin, penyayang binatang, serta mempunyai waktu yang cukup untuk merawat burung sehingga lebih dekat dan lebih akrab.

\section{DAFTAR PUSTAKA}

Mulyana, A. 1995. Burung Bayan Sumba dan Permasalahannya. Prosiding. Balai Penelitian Kehutanan Kupang.

Prijono, N.S. dan S. Handini. 1996. Memelihara, Menangkar, dan Melatih Nuri. Penebar Swadaya. Jakarta.

Ringa, F. 2000. Pola Aktivitas Harian, Perilaku Makan, dan Perilaku Kawin Burung Bayan (Eclectus roratus cornelia) di Stasiun Penangkaran Satwa Liar Oilsonbai, Kupang Barat. Skripsi. Fakultas Matematika dan Ilmu Pengetahuan Alam. Universitas Katolik Widya Mandira. Kupang.
Saka, N.T. dan Y. Lepa. 1994. Perilaku Makan dan Kawin Burung Kakatua Jambul Jingga (Cacatua sulphurea citrinocristata) di Cagar Alam Langgaliru, Sumba Timur. Kupang.

Sudjana. 1992. Metode Statistika. Penerbit Tarsito. Bandung.

Takandjandji, M., E. Sutrisno, dan R. Garsetiasih. 2000. Teknik Konservasi Penangkaran Burung Bayan Sumba. Buletin Kehutanan dan Perkebunan I (2). Bogor.

Takandjandji, M. 2005. Karakteristik Burung dari Pulau Sumba. Majalah Kehutanan Indonesia. Edisi IV. Jakarta.

Tanudimadja. 1978. School of Environmental Conservation Management. Ciawi, Bogor.

Wodzicka-Tomaszewska, M., I K Sutama, I G Putu, dan T.D. Chaniago. 1991. Reproduksi, Tingkah Laku, dan Produksi Ternak di Indonesia. Penerbit PT Gramedia Pustaka Utama. Jakarta. 